Acta Universitatis Nicolai Copernici • Pedagogika XLI/1/2021

Nauki Humanistyczno-Społeczne • Zeszyt 453

DOI: http://dx.doi.org/10.12775/AUNC_PED.2021.008

\author{
Sławomir Sobczak \\ Siedlce University of Natural Sciences and Humanities \\ ORCID: 0000-0001-5215-0607 \\ Tamara Zacharuk \\ Siedlce University of Natural Sciences and Humanities \\ ORCID: 0000-0001-7306-5436

\section{RESEARCH ON THE QUALITY OF UNIVERSITY Classes in the Context of Their Climate}

\begin{abstract}
The transmission of knowledge is not merely the selection of appropriate teaching methods; it is also influenced by personal interactions. This study explored the influence of student-teacher interpersonal relationships and the influence of these interactions on students' opinions of the quality of education. The primary objective was to understand aspects that compel a student to attend classes taught by a particular teacher. The study acquired data on 540 students and 270 lecturers. It hypothesized that the higher the degree of positive student-teacher interactions, the higher the students' evaluation of class quality. The correlation was found to be positive and statistically significant at 0.01 level (Pearson's correlation coefficient of 0.636).

Key w ord s: higher educational process, quality of classes, classes climate, student, lecturer
\end{abstract}




\section{Streszczenie}

Przekazywanie wiedzy to nie tylko dobór odpowiednich metod nauczania, ale także interakcje międzyludzkie. W niniejszym opracowaniu badano oddziaływanie relacji interpersonalnych student - nauczyciel oraz wpływ tych interakcji na opinie studentów o jakości kształcenia. Głównym celem było poznanie aspektów, które skłaniają studenta do uczęszczania na zajęcia prowadzone przez konkretnego nauczyciela. W badaniu zebrano dane dotyczące 540 studentów i 270 wykładowców. Postawiono hipotezę, że im wyższy stopień pozytywnych interakcji student - nauczyciel, tym wyższa ocena jakości zajęć przez studentów. Na podstawie analiz stwierdzono, że korelacja ta jest dodatnia i istotna statystycznie na poziomie 0,01 (współczynnik korelacji Pearsona 0,636).

Słow a kluc zowe: proces kształcenia w szkole wyższej, jakość zajęć, klimat zajęć, student, wykładowca

\section{Introduction}

Tt seems to us that the most important components of the educationIal process, and not only in higher education institutions, are evaluations of the classroom atmosphere and the level of quality of education $^{1}$. Both are based on a wealth of impressions and interpretations. In studies we reviewed on the quality of teaching and the social climate, no analyses were found regarding the relationship between the teaching methods used as part of the quality of education and the quality of the classroom atmosphere. Therefore, it was decided to answer the question: Is there a correlation between the quality of classes and the climate during classes? The present study focused on the effects of personal relations that accompany interactions between a lecturer and a student in the course of the educational process.

A system examining the quality of education comprised two primary elements, namely an element corresponding to the potential of a uni-

1 V. Ruus, et al., Students' well-being, coping, academic success, and school climate, "Social Behavior and Personality", 35/7 (2014), 919-936. 
versity and an external element concerning the control of the potential within the university ${ }^{2}$. External quality assurance is described as an output control promoting accountability and a funding system based on output measures to determine whether a university fulfils the agreed or predetermined standards, whereas internal quality assurance is described as promoting the improvement of the mechanisms implemented within the university to ensure that it satisfies its objectives and the general standards of discipline and profession ${ }^{3}$. The external element is crucial for higher education because a university cannot be detached from the array of interconnected institutional and social factors. An educational institution must fulfil certain societal requirements and institutional expectations ${ }^{4}$. In the present study, the internal element of the university corresponding to the potential of education is more crucial.

In the relevant literature, the quality of education is generally defined as actions taken to ensure the proper functioning of an institution with the anticipated results ${ }^{5}$. According to this view, a university is conceived of as a thriving business that meets specified objectives ${ }^{6}$. The institutional goal is not only to educate but also to steer students towards their future careers. Since nowadays the effectiveness of teaching is measured by the number of graduates employed after graduation, a university's interest in graduates' careers is not only dictated by genuine concern about another person, but it is also meets the formal requirements to meet the criteria by which these institutions are as-

${ }^{2}$ F. Ansah, Conceptualising External and Internal Quality Assurance in Higher Education: A Pragmatist Perspective, "International Journal of African Higher Education", 2/1 (2016), 135-152.

3 M. Martin, A. Stella, External quality assurance in higher education: Making choices, Paris: UNESCO: International Institute for Educational Planning, 2007, 41-42.

${ }^{4}$ W.Y. Lee, Culture and Institutional Climate: Influences on Diversity in Higher Education, "The Review of Higher Education", 25/3 (2002), 359-368.

5 A. Lizzio, K. Wilson, R. Simons, University students' perceptions of the learning environment and academic outcomes: Implications for theory and practice, "Studies in Higher Education", 27/1 (2002), 27-52.

${ }^{6}$ G. Ghaith, The relationship between forms of instruction, achievement and perceptions of classroom climate, "Educational Research", 4/1 (2003), 83-93. 
sessed ${ }^{7}$. We shall skip here the discussion on the role of the university and the question of how it should educate: that is, whether solely with regard to students' future professions or whether solely purely academic education should be of utmost priority. Most probably of the answer to the problem lies in the exclusive alternative approach to the issue, the philosophy of golden mean, known since the time of Aristotle, presents a sensible way out of this dilemma.

The question of how to educate is crucial in terms of higher education $^{8}$. This process is affected by various components, including the choice of teaching and methods content with regard to competencies and skills of students required by the future job market ${ }^{9}$. Moreover, students must be provided knowledge that enhances their cognitive horizons and helps them adapt to social networks and various institutional structures because an individual with well-developed cognitive faculties for understanding and reasoning is less susceptible to manipulation. Therefore, the quality system for higher education must consider and explore each aspect of actions that may contribute to the success of the an educational process ${ }^{10}$.

The didactic process is a purposeful encounter between a teacher and a student, wherein the participants maintain a distinct psychic and social identity. This personal encounter results in an interaction. In the educational process, such mutual personal relations are necessary ${ }^{11}$

7 P. Walker, What Do students think they (should) learn at college? student perceptions of essential learning outcomes, "Journal of the Scholarship of Teaching and Learning", 8/1 (2008), 45-60.

8 H. Nadiri, J. Kandampully, K. Hussain, Students' perceptions of service quality in higher education, "Total Quality Management", 20/5 (2009), 523-535.

9 S.A. Ambrose, et al., How Learning Works: Seven Research-Based Principles for Smart Teaching, San Francisco, 2010, 70-71.

$10 \mathrm{~J}$. Brennan, U. Teichler, The future of higher education and of higher education research, "Higher Education", 56/3 (2008), 259-264; C. Koth, C. Bradshaw, P. Leaf, A multilevel study of predictors of student perceptions of school climate: The effect of classroom-level factors, "Journal of Educational Psychology", 100/1 (2008), 96-104.

11 X. Oriol, et al., Emotional Creativity as Predictor of Intrinsic Motivation and Academic Engagement in University Students: The Mediating Role of Positive Emotions, "Frontiers in Psychology", 7 (2016), 1243. 
at least until the final exam. A lecturer offers a certain product in the form of knowledge, competencies, and skills, and a student is the recipient of this product. Disregarding some negative conditions, such as poor quality teaching or any indispositions of a student (e.g., intellectual laziness), and assuming that the teacher possesses relevant competencies and the student wants to acquire them ${ }^{12}$, there arises a question of what is the optimal way of transferring the knowledge. Finding the answer to this question is the main task of educators, who also deal with the issue of quality of education in reference to the effectiveness of certain didactic methods ${ }^{13}$.

The quality of education depends, inter alia, on the teaching content and the ways in which it is conveyed. These aspects play a vital role in a student's preparation for future professional activities by widening cognitive horizons as well as shaping social, intellectual, and practical competencies that are indispensable for proper functioning in the contemporary world ${ }^{14}$. Although students cannot foresee whether the offered teaching content will be adequate for their future professional needs and will impact personal development, they know whether their expectations are being met, whether the methods are suitable, the language of instruction and explanation is clear and comprehensible, and the course is interesting and encourages further inquiry into the subject. One could also add to the list whether the teaching content is pure theoretical knowledge or whether, apart from the presented theory, the teacher also demonstrates its practical applications to real life. The quality of education may be said to be the students' impressions connected with their participation in academic courses, in the didactic transfer ${ }^{15}$.

12 E.N. Bridwell-Mitchell, N. Cooc, The Ties That Bind: How Social Capital Is Forged and Forfeited in Teacher Communities, "Educational Researcher", 45/1 (2016), 7-17.

13 P. Ginns, M. Prosser, S. Barrie, Students' perceptions of teaching quality in higher education: The perspective of currently enrolled students, "Studies in Higher Education", 32/5 (2007), 603-615.

14 C. Kong, Classroom learning experiences and students' perceptions of quality of school life, "Learning Environment Research", 11/2 (2008), 111-129.

15 M. Mo Ching Mok, Determinants of students' quality of school life: A path model, "Learning Environment Research", 5 (2002), 275-300. 
In the process of delivering higher education, two elements are of paramount importance: the selection of teaching content and appropriate selection of the means for conveying the content. The conveyance of scientific information may be mechanically equated with the selection of appropriate teaching methods. However, even the most optimal teaching methods fail if the relationships among the participants are ambivalent or hostile ${ }^{16}$.

Our investigation into the quality of classes relied on the outcomes rather than the causes: that is, the study aimed at examining students' feelings on how the teaching content was delivered by a lecturer.

Can the quality system of the education be discussed without examining the quality of the didactic process? Rutter and Maughan ${ }^{17}$ state that it is not. When this question, which may be considered a rhetorical question, is satisfactorily answered, we must consider the personal relationship between the lecturer and their students ${ }^{18}$.

As far as classroom atmosphere is concerned, one must pay attention to the result of personal relationships in the classroom. If a particular individual does not feel part of these relationships, that individual will develop an aversion to the classroom ${ }^{19}$. It seems that a positive perception of the atmosphere, the feeling of pleasure that arises from being with others, may be associated without considering other issues that possibly influence this feeling. Furthermore, it seems justified to assume that the better is the atmosphere in a particular social context, the more willingly and with pleasurable associations an individual will return. We believe that the issue of what constitutes a good atmosphere, the likely factors that contribute to it, may be ignored without detriment to the in-

16 S. Black, J. Allen, Part 4: Academic Self-Concept and Emotions, "The Reference Librarian", 59/1 (2018), 42-55.

17 M. Rutter, B. Maughan, School effectiveness findings 1979-2002, "Journal of School Psychology", 40/6 (2002), 451 -475.

18 C. Leonard, S. Bourke, N. Schofield, Affecting the affective: Affective outcomes in the context of school effectiveness, school improvement and quality schools, "Issues in Educational Research", 14/1 (2004), 1-28.

19 D. Tyson, L. Linnenbrink-Garcia, N. Hill, Regulating Debilitating Emotions in the Context of Performance: Achievement Goal Orientations, Achievement-Elicited Emotions, and Socialization Contexts, "Human Development", 52/6 (2009), 329-356. 
terpretation of the study, as our primary objective was to find out what makes a student want to attend classes taught by a particular teacher rather than to investigate what the causes of this fact may be. The willingness to be together is the notion of what one can intuitively describe as the "good atmosphere" of a given institution ${ }^{20}$.

Emotions are typically in either a negative or a positive way ${ }^{21}$; therefore, it may be assumed that it would be relatively easy to evaluate relationships in particular groups and thus evaluate the classroom atmosphere $^{22}$.

The present work focuses on the effects of personal relationships within the interaction between the teacher and the student. The way of transmitting scientific information does not just boil down to the selection of appropriate teaching methods but it is also a purposeful encounter that results in mutually emotional reaction. Obtaining information about students' willingness to participate in a class could be found in their evaluations of classroom atmosphere, which was assumed to be a measure of the degree of students' acceptance of the lecturers' methods and selected content. Evaluation of the level of education was treated as a result of students' impressions related to their participation in classes. Among other factors, these impressions include their feelings about the student - teacher emotional bond, which in turn creates a specific environment for conveying scientific knowledge.

Based on the conclusions of Deyoung ${ }^{23}$, it was assumed that the quality of classes was one of the elements that contributed to the improvement of the class atmosphere. Deyoung ${ }^{24}$ states that the social climate during academic classes is a flexible structure that an academic teacher can use

20 R. H. Moos, Evaluating classroom learning environments, "Studies in Educational Evaluation", 6/3 (1980), 239-252.

21 A. Rowe, J. Fitness, Understanding the Role of Negative Emotions in Adult Learning and Achievement: A Social Functional Perspective, "Behavioral Sciences", 8/2 (2018), 27.

22 P. Niedenthal, S. Krauth-Gruber, F. Ric, Psychology of Emotion: Interpersonal, Experiential and Cognitive Approaches, London, 2006.

23 A.J. Deyoung, Classroom Climate and Class Success A Case Study at the University Level, "The Journal of Educational Research", 70/5 (1977), 252-257.

${ }^{24}$ Ibidem. 
for more effective teaching and that it contributes to a better assessment of the students' functioning during classes. As Chalmers ${ }^{25}$ states, of key importance for the quality of education is the atmosphere in class.

According to Hallinan ${ }^{26}$, attachment translates into positive assessment of the attachment figure, who, because of reciprocity, can demand and expect more. However, it must be borne in mind that the teacher is not the sole creator of the quality of interpersonal relations. Personal relations are bilateral, and thus in order to create reciprocity, or, in the context of this study, the feeling of willingness to be together, both sides must derive pleasure at the psychical level from each other's presence. In other words, high assessment of the atmosphere during classwork will depend on both lecturers and students, and the effects of their relations will be observable in the evaluation of the quality of education.

Prior to the analysis of the obtained results, it was hypothesized that the higher the degree of positive emotional reactions signaled in the form of mutual amity and cordiality, the higher the evaluation of the academic community regarding the quality of classes conducted by a given lecturer.

To verify the main hypothesis, auxiliary analyses were carried out, which enabled estimation of differences of opinion (regarding the level of education quality and class atmosphere) in the group of students as well as lecturers. In addition, the results of intra-group analyses in the following stage will be used to compare both groups of respondents with regard to the aspects under study.

The additional three hypotheses were put forward:

1. Students' as well as lecturers' opinions on the assessment of the level of quality of the classes and of classroom climate are not divergent within the respective groups.

2. Students as well as lecturers do not assess the quality of the classes and the classroom atmosphere differently with regard to the type of university classes (lectures, tutorials, laboratory classes).

25 D. Chalmers, A review of Australian and international quality systems and indicators of learning and teaching, Australia, 2007, 92-95.

26 M.T. Hallinan, Teacher Influences on Students' Attachment to School, "Sociology of Education", 81/3 (2008), 271-283. 
3. Independent of the type of the class, the average level of atmosphere and of the quality of the classes in the opinion of students and in the opinion of lecturers does not differ.

Hypothesis 2 is a specific case of hypothesis 1 and is based on the findings of Devlin and Samarawickrema ${ }^{27}$. The specification of the hypothesis was adopted on the basis of the conclusions of Devlin and Samarawickrema ${ }^{28}$, who stated that the same phenomenon should be studied in different contexts.

In this study, a high value for this indicator indicates that the atmosphere is good, while a low one indicates a low quality of education and a bad class atmosphere. It must be borne in mind that the present study was based on opinions on the range of perceptions concerning classroom atmosphere, and thus one cannot interpret its results in the light of Moos's ${ }^{29}$ conception, which states that the quality of atmosphere in an institutionalized context is better when the results for the particular groups are close to one another.

The present study makes use of a diagnostic survey, with the questionnaire as its instrument. The questionnaire aimed at determining the mean assessment value corresponding to the atmosphere of the conducted classes and their quality.

\section{Methods}

\section{Participants}

The respondents were drawn from students and lecturers in two university faculties. The analysis was carried out on 810 responses: 270 from undergraduate students, 270 from master students, and 270 from lecturers.

27 M. Devlin, G. Samarawickrema, The criteria of effective teaching in a changing higher education context, "Higher Education Research \& Development", 29/2 (2010), 111-124.

28 Ibidem.

29 R. H. Moos, Evaluating correctional and community settings, New York, 1975. 


\section{Instrument}

The study took into account three types of class: lecture, tutorial, and laboratory classes. The instrument was a questionnaire.

In general, the evaluation tool consisted of two parts:

I. Atmosphere in classes:

- atmosphere during classes: evaluation of interpersonal relationships between students and lecturers, evaluation of satisfaction resulting from student-lecturer contacts in the course of studies (2 items).

- assessment of the classes' atmosphere: assessing the degree of the climate of kindness during academic classes (2 items).

- level of the classroom atmosphere: general assessment of the level of classroom atmosphere (1 item).

II. Quality of classes:

- adjusting the scope of classes to the future professional profile of the student: assessment of suitability of the teaching content with regard to students' future professions (2 items).

- use of practical examples: assessment of the teaching content with regard to combing theory with practice (2 items).

- activating students: assessment of the use of activating methods during academic classes (2 items).

- opportunity for students to voice their own opinions: assessment of the ways in which students are encouraged to state their opinions or emotionally express themselves during academic classes (4 items).

- level of satisfaction with the quality of classes: general assessment of the level of satisfaction with the quality of academic classes (1 item).

Statistical analyses were carried out to reliably determine the correlation between the assessment of perceived atmosphere in academic classes and the level of quality of education. 


\section{Procedure}

The data for this study was collected from students and lecturers, who studied and worked at universities. Letters with surveys were sent to universities asked for their dissemination and completion. Participants returned their survey in a sealed envelope to the administration of the university, who then handed them back to the principal investigator. The survey included a cover letter and consent form that informed participants about the purpose of the study. Participants were asked to complete the survey as part of a study on quality of classes and climate during classes. Participation was voluntary and participants were informed that their responses would remain anonymous and confidential.

A given respondent, regardless of whether student or lecturer, could fill in more than one questionnaire, provided they were for different types of classes.

The following variables and coefficients were employed. "Climate during classes" constituted an independent variable. "Academic community" and "Type of class" were independent mediator variables, with "Student" and "Academic teacher" as the coefficients in the former case, and "Lecture", "Tutorial," and "Laboratory class" as the coefficients in the latter one. "Quality of classes" constituted a dependent variable. Members of these two groups of the academic community were asked to evaluate the quality of conducted classes with regard to the following five aspects: adjustment of the scope the class to the future professional profile of the student, lecturer's use of practical examples, activating students during the class, possibility to voice individual opinions by students, and possibility to evaluate the quality of the class by students. The quality of education and how its level is evaluated constitutes the other issue examined in this study.

When determining the quality of education, it was necessary to take into account the types of classes because depending on the type of classes (lectures, tutorials, laboratory classes), the lecturer uses different teaching methods. The analysis assumes the same types of methods for all types of university classes for comparison. The most important methods of conducting classes were distinguished on the basis of factor 
analysis. The resulting consistency in conducting this study meant that the same condition was applied to the atmosphere in particular types of academic classes.

A principal components analysis with a varimax rotation resulted in four factors corresponding to methods of teaching. All four of the methods teaching items was loaded 0.70 or higher and all of the cross-factor loadings were less than $0.20(\alpha=0.764)$.

The respondents were asked for scalar assessment of the level of atmosphere during the classes and quality of classes. Participants marked their responses on a five-point Likert-type scale with anchors (1) strongly disagree to (5) strongly agree, except one coefficient "level of the classroom atmosphere" where respondents indicated their response on a four-point Likert-type scale with anchors (1) strongly disagree to (4) strongly agree.

Then for both variables their coefficients were added and converted on the sten score, based on the recommendations of PsychAssessment (2020, March 17). A sten score of 5 or 6 is regarded as average and it was what is achieved by about one-third of the respondents.

The academic community's opinions on the quality of classes and the atmosphere during them constituted the subject of this research. The study aimed to determine the mean level of quality of classes and class atmosphere, to ascertain statistically significant differences in the evaluation of climate by the academic community with regard to the type of classes (lecture, tutorial, laboratory class), and specify the correlation between the quality of classes and their atmosphere. To this end, the following analyses were carried out.

The employed statistics encompassed the measures of central tendencies and dispersion, the ANOVA analysis, the least significant difference (LSD) test, Duncan's test, Kruskal-Wallis's test, the chi-square test, regressive analysis, and reliability analysis.

\section{Results}

Cronbach's correlation equaled 0.866 on the basis of standardized positions for 8 coefficients: class atmosphere, quality of classes and its co- 
efficients, adjustment of the scope of classes to the future professional profile of the student, use of practical examples, activating students, opportunity for students to voice their own opinions and to assess the quality of classes. A degree of reliability between the examined features was established. The correlation between Cronbach's means was 0.811.

Table 1 shows the response rates regarding the academic community's assessment of the climate and quality of university classes with regard to the type of class.

Table 1

Regression analysis between the quality of classes and the class atmosphere

\begin{tabular}{lccccc}
\hline & \multicolumn{2}{c}{$\begin{array}{c}\text { Unstandardized } \\
\text { coefficients }\end{array}$} & $\begin{array}{c}\text { Standardized } \\
\text { coefficients }\end{array}$ & $\mathbf{t}$ & $\mathbf{p}$ \\
\cline { 2 - 5 } model & $\mathbf{B}$ & Std. Error & Beta & & \\
\hline class atmosphere & 1.455 & .054 & $.636^{* *}$ & 27.038 & .000 \\
\hline (constant) & 8.216 & .346 & & 23.701 & .000 \\
\hline
\end{tabular}

**. Pearson's correlation significant at the level of 0.01 (bilateral).

Note. $\mathrm{B}=$ Values for the regression equation for predicting the dependent variable using the independent variable. Std. Error $=$ The standard errors associated with the coefficients. Beta $=$ The standardized coefficients. $\mathrm{t}$ and $p=$ The $\mathrm{t}$-value and two-tailed $\mathrm{p}$-value used for testing the null hypothesis that the coefficient/parameter is 0 .

$\mathrm{N}=810$; quality of classes $\mathrm{M}=6.71, \mathrm{SD}=2.727$; class atmosphere $\mathrm{M}=6.08$, and $\mathrm{SD}=3.165$.

The ANOVA allows for a linear regression analysis between the academic community's assessment of atmosphere and the quality of classes because $\mathrm{F}(1,1078)=731.045(p<0.001)$. The independent variable reliably predicts the dependent variable.

The simple linear regression model that we tested explained the variability of the variable: quality of university classes (constant) in the variability of the predictor (class climate at university). The unstandardized coefficient for the atmosphere for all types of classes in the assessment of the academic community was $\mathrm{B}=1.455$ (standard error: 
0.054), while that for the constant (quality of classes) was $\mathrm{B}=8.216$ (standard error: 0.346).

Pearson's correlation amounted to $\mathrm{R}=0.636$ at 0.01 significance. The correlation was found to be positive and statistically significant $\left(\mathrm{R}^{2}=0.404\right)$ and corresponded to the percentage of the variation explained: that is, we can say that in $40 \%$ of the cases the perception of the quality of classes depends on the emotional relationship that exists between the student and the academic teacher. Based on the data, it can be concluded that as the atmosphere of emotional reciprocity between the student and the lecturer improves, the assessment of the quality of classes also increases only in $40 \%$ of cases. The remaining $60 \%$ of the variation in the quality of classes is presumed to be due to random variability.

According to students, on average, lectures are very bad (10\%), bad (62\%), satisfactory (27\%), and good (1\%). Not a single respondent rated the lectures as very good. As far as tutorials were concerned, students found them to be very bad (8\%), bad (32\%), satisfactory (48\%), and good (12\%). Again, not a single respondent assessed the tutorial as being very good. Finally, the quality of laboratory classes was assessed to be bad (20\%), satisfactory (62\%), and good (17\%). Only $1 \%$ of respondents said that the laboratory classes were very good.

The totality of the students' responses with respect to the quality of classes makes it possible to calculate average responses for the whole group irrespective of the class type. The students stated that the level of classes was very bad (6\%), bad (38\%), satisfactory (45.5\%), good (10\%), and very good (only $0.5 \%$ ). In total, $44 \%$ of the students rated their classes as either very bad or bad, with a further $45.5 \%$ considering their classes to be satisfactory and $10.5 \%$ finding them good or very good.

For the equinumerosity of this study, the expected $\mathrm{N}$ for the total of 540 students is 108 . There were 32 students who described the quality of the class as very bad, 205 rated it as bad, 246 felt it was satisfactory, and 55 found it to be good. Only 2 students stated that the quality of the class was very good.

No equinumerosity was found among the students with respect to individual categories of the assessment scale. Among the students, the 
chi-square is $\chi^{2}(4)=147.6$, and $p<0.001$. The students' opinion on the quality of classes was not split; most of them reported the quality of classes to be satisfactory or bad.

The lecturers in the study claimed the quality of their lectures to be satisfactory (16\%), while as many as $77 \%$ of them considered their lectures to be good, and $7 \%$ rated them as very good. According to them, the quality of their tutorials was satisfactory (7\%), good (67\%), or very good (26\%). The quality of laboratory classes was rated by lecturers as satisfactory (7\%), good (57\%), or very good (36\%).

The academic teachers assessed their courses at a high level. According to the lecturers, the quality of their classes was either satisfactory $(10 \%)$ or good/very good (90\%). None of the lecturers in the study rated their classes as bad or very bad.

As regards the group of lecturers in this study, the expected $\mathrm{N}$ for the total of 270 is 90 . Twenty-six lecturers rated the quality of the class as satisfactory, 183 rated it as good, and 61 found the quality to be very good. The result of the test among lecturers is similar to that among students. Here the significance of chi-square is $\chi^{2}(2)=47.4$, and $p<0.001$. The lecturers' opinion on the quality of classes was not split; most of them reported the quality of classes to be good or very good

Students have a clear view of the quality of the classes, as indicated by their responses using a 5-level Likert scale. Most students (246 out of 540) rated the classes as satisfactory. Lecturers, too, have a clear view of the quality of their classes. They (183 out of 270) find them to be good. This means that there is a marked difference between students' and lecturers' perceptions of the quality of the classes.

Duncan's test was used to identify 5 homogenous groups out of 6 possible groups. The students' evaluation of the quality of teaching with respect to the type of class differed in a statistically significant way. The laboratory classes were judged the most highly by the students, with an average of 5.25. A lower assessment was given to tutorials, for which the average was 4.77, and the difference was statistically significant. The worst average (3.67) was for lectures. Lecturers likewise rated the lectures the worst, the average standing at 8.67. This result significantly differs, statistically speaking, from academic teachers' evaluation of tutorials (8.90) and laboratory classes (9.03). The dif- 
ference between the latter two averages is not statistically significant ( $p=0.127$ ). In addition, it can be stated that the students rated all class types worse than did the lecturers, and the difference was statistically significant. The results were significant at the $p<0.05$ level.

Table 2

Differences between the average level of quality for types of classes

\begin{tabular}{llllll}
\hline \multicolumn{1}{c}{ academic community } & $\mathbf{1}^{*}$ & $\mathbf{2}^{*}$ & $\mathbf{3}^{*}$ & $\mathbf{4}^{*}$ & $\mathbf{5}^{*}$ \\
\hline Student participating in a lecture & 3.67 & & & & \\
\hline Student participating in a tutorial & & 4.77 & & & \\
\hline $\begin{array}{l}\text { Student participating in a Labo- } \\
\text { ratory class }\end{array}$ & & 5.25 & & \\
\hline Teacher conducting a lecture & & & & \\
\hline Teacher conducting a tutorial & & & & & \\
\hline $\begin{array}{l}\text { Teacher conducting a laboratory } \\
\text { class }\end{array}$ & & & & & 9.67 \\
\hline Significance & 1.000 & 1.000 & 1.000 & 1.000 & .127 \\
\hline
\end{tabular}

Note. From 1 to 5 groups of significantly different average. *Subset for alpha $(\alpha)=.05$.

The ANOVA test revealed that the difference between the means for all groups was statistically significant $(p<0.001)$. Therefore, post hoc tests were applied to carry out a more detailed analysis between all groups of investigated variables.

Statistically significant differences were found in the academic community's evaluations of the quality of classes with respect to different class types (lectures, tutorials, and laboratory classes) and the people evaluating them. The differences across all groups are significant, at 0.05 level.

As regards the differences in the results between teachers conducting tutorials and teachers conducting laboratory classes, these are not statistically significant as $\mathrm{p}=0.555$.

The difference between the students' and lecturers' evaluation of the quality of lectures was statistically significant $(p<0.001$; difference in means: -133.27 ). 
The difference between the students' evaluation of the quality of lectures and the lecturers' evaluation of the quality of tutorials was statistically significant ( $p<0.001$; difference in means: -151.72$)$.

The difference between the students' evaluation of the quality of lectures and the lecturers' evaluation of the quality of laboratory classes was statistically significant ( $p<0.001$; difference in means: -156.72$)$.

The difference between the students' evaluation of the quality of tutorials and the lecturers' evaluation of lectures is statistically significant ( $p<0.001$; difference in means: -98.98).

The difference between the students' and lecturers' evaluation of the quality of tutorials was statistically significant $(p<0.001$; difference in means: -117.43 ).

The difference between the students' evaluation of the quality of tutorials and the lecturers' evaluation of laboratory classes is statistically significant ( $p<0.001$; difference in means: -122.43$)$.

The difference between the students' evaluation of the quality of laboratory classes and the lecturers' evaluation of lectures is statistically significant ( $p<0.001$; difference in means: -73.32).

The difference between the students' evaluation of the quality of laboratory classes and the lecturers' evaluation of tutorials is statistically significant ( $p<0.001$; difference in means: -91.77).

The difference between the students' and lecturers' evaluation of the quality of laboratory classes was statistically significant $(p<0.001$; difference in means: -96.77).

The difference between the students' evaluation of the quality of lectures and tutorials was statistically significant $(p<0.001$; difference in means: -34.29 ).

The difference between the students' evaluation of the quality of lectures and laboratory classes was statistically significant $(p<0.001$; difference in means: -59.95 ).

The difference between the students' evaluation of the quality of tutorials and laboratory classes was statistically significant (approximate $p=0.002$; difference in means: -25.66 ).

The difference between the lecturers' evaluation of the quality of lectures and tutorials was statistically significant (approximate $p=0.047$; difference in means: -18.45$)$. 
The difference between the lecturers' evaluation of the quality of lectures and laboratory classes was statistically significant (approximate $p=0.019$; difference in means: -23.45 ).

The lecturers tended to evaluate their classes better than did students, and that difference was statistically significant.

On the basis of the responses from members of the academic community, one may conclude that the quality of lectures ranges from very bad (7\% of the respondents), to bad (41\%), satisfactory (23\%), good (27\%), and very good (2\%). The quality of tutorials is, according to the academic community, very bad (6\%), bad (21\%), satisfactory (34\%), good (30\%), and very good (5\%). The quality of laboratory classes is bad (13\%), satisfactory (43\%), good (30\%), and very good (14\%). The totality of the academic community's responses with respect to the quality of classes makes it possible to calculate average responses for the whole group irrespective of the class type. According to the academic community under study, the quality of classes ranges from very bad (4\%), to bad (25\%), satisfactory (34\%), good (29\%), and very good (8\%). A total of $29 \%$ of the respondents found the classes to be very bad or bad, a further 34\% rated them as satisfactory, and 37\% were satisfied with the quality of the classes and marked them as either good or very good.

For the equinumerosity of this study, the expected $\mathrm{N}$ for the total of 810 is 162 . There were 35 respondents who rated the quality of classes as very bad, while 203 opted for bad, 270 chose satisfactory, 235 found it to be good, and 67 judged it as very good. No equinumerosity was found for individual levels of class quality evaluation. The significance of the chi-square test in the sample is $\chi^{2}(4)=82.8(p<0.001)$. Hence, the academic community was not split with respect to the opinion of the quality of classes.

The academic community has a clear view when it comes to the quality of classes on the 5-point Likert scale, which is indicated by the highest result. Most members of the academic community rated their classes as satisfactory (270 (34\%) out of 810$)$.

According to the responses from the academic community, the average rank with respect to the quality of lectures was 109.9, and in the case of tutorials and laboratory classes it stood at 138.9 and 157.7, respec- 
tively. According to the Kruskal-Wallis test, $\mathrm{H}(2)=18.571(p<0.001)$. Significant differences were found in the respondents' opinions on the quality of particular types of classes.

The students stated that the average level of climate during lectures, tutorials, and laboratory classes was very bad in $16.6 \%$, bad in $43.9 \%$, good in $28.9 \%$, and very good in $10.6 \%$ of cases. As far as lectures are concerned, $20 \%$ of the students assessed the average level of climate during them as very bad, $45 \%$ stated that it was bad, $25 \%$ of respondents described it as good, and $10 \%$ as very good. Twenty percent of the respondents from the same group rated the average level of climate during tutorials as very bad, $40 \%$ assessed it as bad, $26.7 \%$ felt that the climate was good, and $13.3 \%$ felt that it was very good. With regard to the climate in the laboratory classes, $10 \%$ of the students described it as very bad, $46.7 \%$ as bad, $35 \%$ as good, and $8.3 \%$ as very good.

For equinumerosity, the expected $\mathrm{N}$ for the total of 540 is 135. Equinumerosity was not observed at particular levels of the scale of class atmosphere. The significance of chi-square was $\chi^{2}(3)=41.867$ $(p<0.001)$. Thus, there was not much divergence in students' opinions on atmosphere with regard to different types of classes. They had a unanimous opinion with regard to the atmosphere during academic classes, as indicated by the highest mean result on a four-point scale.

Most of the students assessed the atmosphere as bad: 237 (43.9\%) out of 540. With regard to the level of class atmosphere, $327(60.5 \%)$ students indicated it to be very bad and bad, and 213 (39.5\%) assessed it as good and very good.

The lecturers assessed the average level of climate during lectures, tutorials, and laboratory classes as bad (6.7\%), good (62.2\%), and very good (31.1\%). An overall $6.7 \%$ of the teachers assessed the average level of climate as bad, $66.7 \%$ stated that it was good, and $26.7 \%$ described it as very good. Sixty percent of the lecturers reported the average level of atmosphere during tutorials as good, while $40 \%$ assessed it as very good. With regard to the atmosphere in laboratory classes, $13.3 \%$ of the teachers described it as bad, $60 \%$ considered it to be good, and $26.7 \%$ described it as very good.

For equinumerosity, the expected $\mathrm{N}$ for the total of 270 is 90 . Equinumerosity was not observed at particular levels of the scale of class 
atmosphere. The significance of the chi-square test was $\chi^{2}(2)=46.800$ $(p<0.001)$. Thus, there was not much divergence in lecturers' opinions on atmosphere with regard to different types of classes. They had a unanimous opinion with regard to the atmosphere during academic classes, as indicated by the highest mean result on the four-point scale.

Most of the targeted teachers assessed the class atmosphere as good (168 (62.2\%) out of 270). With regard to the level of class atmosphere, $18(6.7 \%)$ lecturers reported it to be bad, 168 (62.2\%) reported it to be good, and 84 (31.1\%) assessed it as very good.

Table 3

Differences between the average level of atmosphere for types of classes

\begin{tabular}{lcc}
\hline \multicolumn{1}{c}{ academic community } & group 1* & group 2* \\
\hline Students participating in a lecture & 5.00 & \\
\hline Students participating in a tutorial & 5.16 & \\
\hline Students participating in a laboratory class & 5.34 & 6.76 \\
\hline Teachers conducting a laboratory class & & 7.30 \\
\hline Teachers conducting a lecture & & 6.90 \\
\hline Teachers conducting a tutorial & .378 & .156 \\
\hline $\boldsymbol{p}$ &
\end{tabular}

Note. $p=$ significance. ${ }^{*}$ Subset for alpha $(\alpha)=0.05$.

The average result for satisfaction with atmosphere on a four-point scale in reference to lectures was 5.00 in the evaluation by the students and 6.90 in the evaluation by lecturers; in reference to tutorials it was 5.16 for the students and 7.30 for the lecturers; and with regard to laboratory classes, the obtained figures were 5.34 and 6.76, respectively.

Neither the students' nor the lecturers' evaluations of class atmosphere differed statistically significantly ( $p=0.378$ and $p=0.156$, respectively). The results were significant at the 0.05 level. On the basis of Duncan's test, it was possible to distinguish two groups of assessments that differed from each other with regard to the mean values.

The ANOVA revealed that the difference between the means for all groups was statistically significant because $p<0.001$. Therefore, post 
hoc tests were applied to conduct a more detailed analysis between all groups of investigated variables.

Statistically significant differences between particular levels of the scale describing the assessment of the class atmosphere and a given type of class were found with regard to the type of participant (i.e., student vs. lecturer). The differences in all groups were significant at the 0.05 level.

Statistically significant differences were noted in the assessment of atmosphere during lectures by the students participating in lectures and the teachers conducting lectures $(p<0.001$; difference in means: $-1.900)$.

There were statistically significant differences in the assessment of atmosphere during lectures by the students participating in lectures and the teachers conducting tutorials $(p<0.001$; difference in means: $-2.300)$.

Statistically significant differences were also found in the assessment of atmosphere during lectures by the students participating in lectures and the teachers conducting laboratory classes $(p<0.001$; difference in means: -1.766 ).

Regarding the atmosphere during classes, statistically significant differences were found in the assessment by the students participating in tutorials and that by the academic teachers conducting lectures ( $p<0.001$; difference in means: -1.734$)$.

Statistically significant differences were noted in the assessment of atmosphere during tutorials by the students participating in them and the lecturers conducting them $(p<0.001$; difference in means: -2.124).

Moreover, there were statistically significant differences in the assessment of atmosphere during tutorials by the students participating in them and the lecturers conducting laboratory classes $(p<0.001$; difference in means: -1.600 ).

With regard to the atmosphere during laboratory classes, statistically significant differences were found in its assessment by the students participating in laboratory classes and the lecturers conducting lectures ( $p<0.001$; difference in means: -1.566$)$. 
Statistically significant differences were also noted in the assessment of atmosphere during laboratory classes by the participating students and the lecturers conducting tutorials $(p<0.001$; difference in means: -1.966 ).

Finally, there were statistically significant differences in the assessment of atmosphere during laboratory classes by the participating students and the lecturers conducting laboratory classes $(p<0.001$; difference in means: -1.434$)$. In all of the above cases, the standard error was at the 0.177 level.

The academic community stated that the average level of atmosphere during lectures, tutorials, and laboratory classes was very bad in $11.1 \%$, bad in $31.5 \%$, good in $40 \%$, and very good in $17.4 \%$. According to the respondents in this group, the average level of atmosphere during lectures was very bad in $13.3 \%$ and bad in $32.2 \%$ of cases. The percentages corresponding to the options good and very good in reference to the atmosphere during lectures were $38.9 \%$ and $15.6 \%$, respectively. As far as the average level of atmosphere during tutorials is concerned, the academic community assessed it as very bad in $13.3 \%$, bad in $26.7 \%$, good in $37.8 \%$, and very good in $22.2 \%$. Finally, with regard to the climate during laboratory classes, $6.7 \%$ of the respondents described it as very bad, $35.6 \%$ described it as bad, $43.3 \%$ of them chose the option good, and $14.4 \%$ of the academic community assessed it as very good.

For equinumerosity of this study, the expected $\mathrm{N}$ for the total of 810 is 202.5. In reference to the level of class atmosphere 90 respondents indicated very bad, 225 respondents marked bad, 324 respondents chose good, and 141 participants assessed it as very good. Equinumerosity was not noted at particular levels of the scale of class atmosphere. The significance of the chi-square test was $\chi^{2}(3)=55.896(p<0.001)$. Thus, the opinions of the academic community did not diverge much in terms of atmosphere according to different types of classes. Their opinion was unanimous with regard to the atmosphere during academic classes, indicated by the highest mean result on a four-point scale. Most of the participants assessed the class atmosphere as good (324 (40\%) out of 810). 
The average result obtained from the academic community concerning their satisfaction with the class atmosphere on a four-point scale was 2.57 for lectures, 2.69 for tutorials, and 2.66 for laboratory classes. The results for the particular levels on the scale for class atmosphere did not differ statistically significantly $(p=0.394)$. $p$ was significant at $<0.05$.

The mean result for the classroom atmosphere corresponded to 2.64; the mode and median were 3 . This means that the academic community was of the opinion that the level of classroom atmosphere was good.

\section{Discussion}

The students rated the quality of education as significantly worse than the lecturers. Additionally, statistically significant differences were also found among the students' evaluations of different types of classes. On the other hand, the lecturers rated the quality of classes in the case of lectures as being significantly lower than in tutorials and laboratory classes. The factors that the respondents evaluated included adjusting the scope of classes to the future professional profile of the student, the use of practical examples, activating the student, and students' ability to voice their opinions. The lecturers themselves said that the lectures contained too few elements related to the quality of class investigated in this study. One might suppose that the lectures included more theoretical aspects than practical ones. In such cases students either have no opportunity, or they have limited opportunity, to voice their opinions, which results in them not being activated during lectures. The situation changes when students attend practical classes such as tutorials or laboratory classes. In such cases, the evaluation of class quality is significantly higher as regards both lecturers and students.

On a four-point scale, the students rated the level of atmosphere to be lower compared with the lecturers: 2 (bad) by the students and 3 (good) by the lecturers.

The students' and lecturers' opinions did not show much divergence, as equinumerosity for the particular categories of assessment was not noted. Therefore, in the context of the above analyses the first research 
hypothesis was verified: that the opinions of respondents on the classroom atmosphere and the quality of university classes are not divergent in both groups. Since neither within the group of students nor within the group of teachers were any significant intra-group differences observed, the second research hypothesis was confirmed: that students and lecturers do not assess the classroom atmosphere differently with regard to the type of university class (lectures, tutorials, laboratory classes). However, both groups under study evaluated the quality of classes at university differently depending on the type of class. The result of the assessment of classroom atmosphere in lectures, classes, and laboratories by the group of students differed statistically significantly from the result obtained from the group of lecturers. Likewise, the result of the assessment of the quality of instruction differed in a statistically significant way from the result obtained from the lecturers' group.

Thus, in this case, the third hypothesis must be rejected as it turned out that the students assessed the classroom atmosphere statistically significantly lower than did the lecturers in all kinds of classes.

Finally, the study's results confirmed the fourth hypothesis: that one may state that the sense of positive classroom atmosphere is positively correlated with the quality of the classes. Specifically, the more intense the feeling of a positive atmosphere, the higher the assessment of the quality of the class.

Official reports concerning the research on quality of education at all educational stages usually ignore the aspect of mutual emotional relationships that take place between students and teachers. It goes without saying that this issue constitutes a vast and complex research area, and hence it does not lend itself easily to a quick investigation. If one embraces the assumption that it is not institutions but humans who educate, then naturally interpersonal relationships must come to the fore as a crucial factor in the assessment of the quality of education.

So far the research on the quality of education at the tertiary level has focused mainly on the students' acquisition of teaching content, also understood as the acquisition of a variety of competencies, with progress measured in reference to the job market. Such an approach disregards the causes that possibly enhance the individual development of the person being educated. As far as the analyses carried out in 
this study are concerned, it is assumed that one such cause is interpersonal relationships, which, as follows from other studies, bring about changes in the social functioning of the individual, facilitate their development, and even generate positive attitudes to the acquisition of educational content.

The initial hypothesis that the classroom atmosphere contributes to the assessment of the quality of education was supported. Even though the present study is at a gross level of generality and the obtained sample is rather small, it allows one to conclude that the quality of education in $40 \%$ of cases depends on the kind of classroom atmosphere. More precisely, this correlation regards a tacit internal relationship of reciprocity revealed in the emotional reaction that a student and a lecturer experience in the classroom context. Therefore, there arises a need for further analyses that would take into account individual interpersonal relationships between particular students and teachers, especially if one pursues the assumption that the sum of interactive dyads corresponds to the totality of the phenomenon. Additionally, such an investigation may reveal a network of interconnections in a given institution, which in turn will point to these teachers who constitute main educational support for the majority of students and who motivate students to undertake educational challenges in life-long education, as obviously the educational process does not end with graduation. In other words, a teacher who is capable of provoking an adequate emotional reaction can act as a stimulus for students' further development.

\section{Conclusions}

Chalmers ${ }^{30}$ states that staff engagement in their professional development is correlated with the quality of student learning. Nevertheless, what is of key importance for the quality of education is the climate of trust between the teacher and the student. A reciprocal relationship resulting from an emotional bond between the academic teacher and

30 D. Chalmers, A review of Australian and international quality systems and indicators of learning and teaching, Australia, 2007, 93-94. 
the student constitutes the basis for student engagement in the higher educational process ${ }^{31}$. Mutual understanding of an efficient teaching-learning process is crucial for ensuring the quality of education at the university level. This understanding must encompass the skills and practices of effective teachers ${ }^{32}$, as well as the ways in which these may be applied in various overlapping contexts ${ }^{33}$.

University teachers' educational work should focus on the aspects of climate and the quality of instruction. Teachers should take care in this regard, as their actions shape the quality of instruction and initiate an appropriate atmosphere of reciprocity. While doing so, they should remember that interpersonal relations are characterized by reciprocity and are thus mutual. The studies suggest that the evaluation of the quality of instruction depends, among other things, on the affective relations that are formed between the academic teacher and the student.

Therefore, further research should concentrate on a full array of assumptions concerning constituent features of social climate including emotional reactions in relation to the assessment of the quality of academic classes. It is believed here that the system of quality of higher education must attend to, and even experiment with, every aspect of action that may lead to success in the educational process.

${ }^{31}$ A. J. Deyoung, J. Alan, Classroom Climate and Class Success A Case Study at the University Level, "The Journal of Educational Research", 70/5 (1977), 252-257.

${ }_{32}$ M. N. Bastedo, E. Samuels, M. Kleinman, Do charismatic presidents influence college applications and alumni donations? Organizational identity and performance in US higher education, "Higher Education" 68/3 (2014), 397-415.

${ }^{33}$ M. Devlin, G. Samarawickrema, The criteria of effective teaching in a changing higher education context, "Higher Education Research \& Development", 29/2 (2010), 111-124. 


\section{References:}

Ambrose, Susan A., Bridges, Michael W., DiPietro, Michele, Lovett, Marsha C., Norman, Marie K. How Learning Works: Seven Research-Based Principles for Smart Teaching. San Francisco: Jossey-Bass, 2010.

Ansah, Francis. 2016. "Conceptualising External and Internal Quality Assurance in Higher Education: A Pragmatist Perspective". International Journal of African Higher Education 2(1): 135-152. DOI: https://doi.org/10.6017/ ijahe.v2i1.9261.

Bastedo, Michael N., Samuels, Elias, Kleinman, Molly. 2014. "Do charismatic presidents influence college applications and alumni donations? Organizational identity and performance in US higher education". Higher Education 68(3): 397-415. DOI: https://doi.org/10.1007/s10734-014-9719-z.

Black, Steve, Allen, James D. 2018. "Part 4: Academic Self-Concept and Emotions". The Reference Librarian 59(1): 42-55. DOI: https://doi.org/10.1080 /02763877.2017.1349022.

Brennan, John, Teichler, Urlich. 2008. "The future of higher education and of higher education research". Higher Education 56(3): 259-264. DOI: https://doi.org/10.1007/s10734-008-9124-6.

Bridwell-Mitchell, E. N., Cooc, North. 2016. "The Ties That Bind: How Social Capital Is Forged and Forfeited in Teacher Communities". Educational Researcher 45(1): 7-17. DOI: https://doi.org/10.3102/0013189X16632191.

Chalmers, Denise. 2007. A review of Australian and international quality systems and indicators of learning and teaching. Carrick Institute for Learning and Teaching in Higher Education Ltd. http://citeseerx.ist.psu.edu/viewdoc/download?doi=10.1.1.169.3919\&rep=rep1\&type $=$ pdf.

Devlin, Marcia, \& Samarawickrema, Gayani. 2010. "The criteria of effective teaching in a changing higher education context". Higher Education Research \& Development 29(2): 111-124. DOI: https://doi. org/10.1080/07294360903244398.

Deyoung, Alan, John. 1977. "Classroom Climate and Class Success A Case Study at the University Level". The Journal of Educational Research 70(5): 252-257. DOI: https://doi.org/10.1080/00220671.1977.10884999.

Ghaith, Ghazi. 2003. "The relationship between forms of instruction, achievement and perceptions of classroom climate". Educational Research 4(1): 83-93. DOI: https://doi.org/10.1080/0013188032000086145. 
Ginns, Paul, Prosser, Michael, Barrie, Simon. 2007. "Students' perceptions of teaching quality in higher education: The perspective of currently enrolled students". Studies in Higher Education, 32(5): 603-615. DOI: https:// doi.org/10.1080/03075070701573773.

Hallinan, Maureen, T. 2008. "Teacher Influences on Students' Attachment to School". Sociology of Education 81(3): 271-283. DOI: https://doi. org/10.1177/003804070808100303.

Kong, Chit-Kwong. 2008. "Classroom learning experiences and students' perceptions of quality of school life". Learning Environment Research, 11(2): 111-129. DOI: https://doi.org/10.1007/s10984-008-9040-9.

Koth, Christine, Bradshaw, Catherine, Leaf, Philip. 2008. "A multilevel study of predictors of student perceptions of school climate: The effect of classroom-level factors". Journal of Educational Psychology, 100(1): 96-104. DOI: https://doi.org/10.1037/0022-0663.100.1.96.

Lee, Wynetta, Y. 2002. "Culture and Institutional Climate: Influences on Diversity in Higher Education". The Review of Higher Education, 25(3): 359-368. Published by Johns Hopkins University Press. DOI: 10.1353/rhe.2002.0014 Access provided by The University of North Carolina at Chapel Hill (2 Feb 2016 16:20 GMT) https://studentsuccess.unc.edu/files/2016/02/25.3lee.pdf.

Leonard, Carl, Bourke, Sid, Schofield, Neville. 2004. "Affecting the affective: Affective outcomes in the context of school effectiveness, school improvement and quality schools". Issues in Educational Research, 14(1): 1-28. http://www.iier.org.au/iier14/leonard.html.

Lizzio, Alf, Wilson, Keithia, Simons, Roland. 2002. "University students' perceptions of the learning environment and academic outcomes: Implications for theory and practice". Studies in Higher Education, 27(1): 27-52. DOI: https://doi.org/10.1080/03075070120099359.

Martin, Michaela, Stella, Antony. 2007. "External quality assurance in higher education: Making choices". Paris, UNESCO: International Institute for Educational Planning. https://unesdoc.unesco.org/ark:/48223/pf0000152045/ PDF/152045eng.pdf.multi.

Mo Ching Mok, Magdalena, 2002. "Determinants of students' quality of school life: A path model". Learning Environment Research, 5: 275-300. DOI: https://doi.org/10.1023/A:1021924322950.

Moos, Rudolf, H. Evaluating correctional and community settings. Hoboken, NJ: John Wiley \& Sons Inc, 1975. 
Moos, Rudolf, H. 1980. "Evaluating classroom learning environments". Studies in Educational Evaluation, 6(3): 239-252. DOI: https://doi.org/10.1016/0191-491X(80)90027-9.

Nadiri, Halil, Kandampully, Jay, Hussain, Kashif. 2009. "Students' perceptions of service quality in higher education". Total Quality Management, 20(5): 523-535. DOI: https://doi.org/10.1080/14783360902863713.

Niedenthal, Paula, Krauth-Gruber, Silvia, Ric, Francois. Psychology of Emotion: Interpersonal, Experiential and Cognitive Approaches. London: Psychology Press, 2006.

Oriol, Xavier, Amutio, Alberto, Mendoza, Michelle, da Costa, Silvia, Rafael, Miranda. 2016. "Emotional Creativity as Predictor of Intrinsic Motivation and Academic Engagement in University Students: The Mediating Role of Positive Emotions". Frontiers in Psychology 7: 1243. DOI: https://doi.org/10.3389/ fpsyg.2016.01243.

PsychAssessment. How to... A practical guide to psychometrics (2020, March 17). http://www.psychassessment.com.au/PDF/HowtoA.pdf.

Rowe, Anna, Fitness, Julie. 2018. "Understanding the Role of Negative Emotions in Adult Learning and Achievement: A Social Functional Perspective". Behavioral Sciences, 8(2): 27. DOI: https://doi.org/10.3390/bs8020027.

Rutter, Michael, Maughan, Barbara. 2002. "School effectiveness findings 1979-2002". Journal of School Psychology, 40(6): 451-475. DOI: https:// doi.org/10.1016/S0022-4405(02)00124-3.

Ruus, Viive-Riina, Veisson, Marika, Leino, Mare, Ots, Loone, Pallas, Linda, Sarv, Ene-Silvia, Veisson, Anneli. 2007. "Students' well-being, coping, academic success, and school climate". Social Behavior and Personality, 35(7): 919-936. DOI: https://doi.org/10.2224/sbp.2007.35.7.919.

Tyson, Diana, Linnenbrink-Garcia, Lisa, Hill, Nancy. 2009. "Regulating Debilitating Emotions in the Context of Performance: Achievement Goal Orientations, Achievement-Elicited Emotions, and Socialization Contexts". Human Development, 52(6): 329-356. DOI: https://doi.org/10.1159/000242348.

Walker, Paul. 2008. "What Do students think they (should) learn at college? student perceptions of essential learning outcomes". Journal of the Scholarship of Teaching and Learning, 8(1): 45-60. https://scholarworks.iu.edu/journals/index.php/josotl/article/view/1687/1685. 